Article

\title{
Does Thinning Intensity Affect Wood Quality? An Analysis of Calabrian Pine in Southern Italy Using a Non-Destructive Acoustic Method
}

\author{
Diego Russo, Pasquale A. Marziliano * ${ }^{\mathbb{D}}$, Giorgio Macri, Andrea R. Proto ${ }^{\circledR}$, Giuseppe Zimbalatti \\ and Fabio Lombardi \\ Department of AGRARIA, Mediterranean University of Reggio Calabria, 89122 Reggio Calabria, Italy; \\ diego.russo@unirc.it (D.R.); giorgio.macri@unirc.it (G.M.); andrea.proto@unirc.it (A.R.P.); \\ gzimbalatti@unirc.it (G.Z.); fabio.lombardi@unirc.it (F.L.) \\ * Correspondence: pasquale.marziliano@unirc.it; Tel.: +39-0965-1694256
}

Received: 15 February 2019; Accepted: 29 March 2019; Published: 2 April 2019

check for updates

\begin{abstract}
In the middle of XIX century, Calabrian pine was planted in southern Italy to increase the forest cover in mountainous areas. Many of these forest stands were never managed, since they were considered non-profitable for wood production. Therefore, in order to promote timber value, it is fundamental to study, more deeply, the characteristics and management options for this species. The acoustic technologies applied to predict the mechanical and physical properties of timber are well-established practices in forest research. In this study, we hypothesized that the tree stand density could influence the dynamic modulus of elasticity (MOEd) and, therefore, the future wood quality. We specifically aimed to verify if different management options, when applied, could influence the timber quality of Calabrian pine growing in similar environmental conditions. The study was conducted in the Aspromonte National Park (Calabria, Southern Italy). We derived the MOEd values from data obtained by the acoustic velocity measured through the TreeSonic ${ }^{\mathrm{TM}}$ timer. Calabrian pine trees were selected in stands where different intensities of thinning were applied eleven years before this study began (no thinning, thinning $25 \%$, thinning $50 \%$, and thinning $75 \%$ ). The percentage refers to the number of trees cut with respect to the total number of occurring trees. The analyses were conducted on a total of 804 trees (201 trees for each intensity of thinning). A strong positive correlation was observed between the acoustic velocity, the thinning treatments and diameter at breast height (DBH). The thinning realized at $25 \%$ induced better tree wood quality. We also analyzed the best predictors for MOEd estimation, using variables easily measurable in the field, such as tree diameter, tree height, or their transformations (number of trees per hectare, basal area per hectare). We provide, here, a useful tool for predicting the wood stiffness in relation to stand parameters easily measurable in forest inventories.
\end{abstract}

Keywords: Pinus nigra Arnold subsp. calabrica; thinning intensity; Mediterranean mountain forests; acoustic velocity; modulus of elasticity; predictors for wood quality

\section{Introduction}

In Southern Europe, the Calabrian pine (Pinus nigra Arnold subsp. calabrica) occurs mainly in Italy (Calabria and Sicilia) and in France (Corsica). In Southern Italy, Calabrian pine forests are strongly related to the complex geological history, lithological and climatic characteristics, and also to the long history of human exploitation of the related forest stands [1]. In the past, Calabrian pine has provided valuable timber useful for building houses and vessels, as well as offering resinous substances (pitch) employed for a variety of purposes [2]. 
This species is particularly common in Sicily and on the Etna Volcano, but is mainly found in the Sila and Aspromonte National Parks in Calabria Region. Calabrian pine covers an area of approximately $114,000 \mathrm{ha}$, mostly characterized by pure stands of natural origin and plantations. The latter originated from extensive reforestation projects carried out between 1950 and 1970 on the basis of a specific Italian state law [3]. These plantations were realized with the aim of reducing the hydrological risk in mountainous areas, but also for facilitating the natural succession toward mixed forests with a significant component of deciduous species [4]. Together with soil and watershed protection, Calabrian pine has an important role in the local forest economy. In order to increase the economic value of these forests, the best silvicultural options should be selected and adopted at stand level, to achieve specific objectives. Therefore, different management practices and related intensities can change the tree species composition and richness and, also, the stand density and tree age distribution [5]. Moreover, management practices can increase the quality and quantity of merchantable timber, reducing also the risks derived from diseases and forest fires [6,7]. Forest management is aimed to create a vigorous stand, increasing tree growth and developing structural characteristics useful for timber production. Furthermore, thinning activities can also favor the creation of new habitats for wildlife, favoring the occurrence of healthy and vigorous forests [8].

Thinning activities control the forest stand density, improving the growth of the remaining trees [9] based on sustainable approaches [10], and decreasing, also, the tree mortality rates from a long-term perspective [11]. Thus, selective thinning should be encouraged for proper and sustainable forest management, supporting the forest stability, productivity, and quality.

Furthermore, forest management can determine variation in the physical and mechanical properties of harvested wood, both at stand and tree level [12]. For this reason, the identification of certain wood properties that can increase timber quality is essential, as it is important to select the best forest management options to improve wood quality.

Wood quality can be described as a set of characteristics that make woody materials economically valuable for their end uses [13]. Briggs and Smith [14] defined wood quality as "a measure of the aptness of wood for a given use". These properties can include, for example, the wood density, the uniformity in tree ring size, the percent of knot-free wood, and the proportion between early wood and late wood.

The objective evaluation of the wood quality and quantity is then critical for quantifying the productive value of a forest $[15,16]$. For this purpose, several non-destructive technologies (NDTs) have been developed in the past years to evaluate the quality of woody materials. For example, at belowground level, (mini) rhizotrons and ground-penetrating radar allows for evaluating tree rooting distribution and growth $[17,18]$. Moreover, at aboveground level, NDT measures allow for evaluation of the mechanical and technological properties of standing trees [19-22]. More specifically, stress wave-based non-destructive acoustic techniques have been extensively investigated during the past few decades [23], resulting in very useful methods for predicting the mechanical properties of woody materials.

The use of stress wave-based non-destructive tests is relatively common in the forest-to-mill woody supply chain in Australia [24] and in North America [25,26], while it is less common in Europe. Specifically, research developments [27] in acoustic sensing technology can, nowadays, permit the estimation of wood quality and intrinsic woody properties for standing trees, stems, and logs. The information derived from NDT measures could be used to sort and grade trees and logs according to their suitability for different end uses, such as structural products, advanced composites, pulp, and paper, and also for bioenergetics purposes.

Among the parameters measurable by acoustic methods, one of the most important is the modulus of elasticity of wood (MOE). The MOE, also known as wood stiffness, is essentially one of the fundamental wood quality parameters and measures the resistance to deflection [28]. For example, it is important since some woody products, such as laminated veneer and dimension lumber, require stiff and strong woody properties [29]. 
The recent literature has focused on determining whether stress wave techniques could be used to determine wood quality [30]. Several studies shown a good relationship between the stress wave-based modulus of elasticity (MOE) and the static MOE of lumber cut from logs [31,32]. This methodological approach is also applied to determine the relationships between the environmental conditions, silvicultural practices, and wood fiber properties [33]. The modulus of elasticity and the density of the woody materials strongly affect the acoustic properties of wood [34]. One of the most important mechanical properties, measurable by NDT methods, is Young's modulus, i.e., the modulus of elasticity (MOEd), which describes the material's stiffness.

Many portable instruments have been developed to measure the wood stiffness of standing trees, logs, and sawn timber using acoustic technology [35]. These instruments are able to measure the speed at which an induced sound (stress) wave propagates through a woody sample, which is proportional to its stiffness [36]. When the stress is applied to the wood surface, the generated disturbance propagates through the wood as stress wave. Several studies have hypothesized that the characteristics of the resulting wave are related to the mechanical properties of the wood [37,38].

Stress wave propagation in wood is a dynamic process correlated to several factors, such as the stand developmental stage [39], genetic characteristics [40,41], and also the silvicultural activities and their intensities [42]. More specifically, the quality and properties of wood are generally affected by silvicultural practices, especially the anthropic control of stand density. Silvicultural practices might not only increase the biomass production of trees, but also improve the quality and the related physical and mechanical characteristics of the wood in trees [43,44].

Furthermore, some authors have reported how high thinning intensities adversely influence the patterns of tree ring width and the tree competitive position within a forest stand [45-47].

Wang [48], examining the effect of thinning treatments on the wood quality of radiata pine, found that trees were characterized by higher acoustic velocity and stiffness mostly occurred in uncut stands and in forests characterized by light and medium intensities of thinning, whereas the lowest values occurred in stands that received the most intensive thinning approaches.

In Southern Italy, Todaro and Macchioni [43] and Proto et al. [16] showed a significant improvement of wood properties induced by a medium thinning operation for Douglas fir and Calabrian pine trees, respectively. Moreover, Cown et al. [49] and Barbour et al. [50] reported that heavy thinning approaches caused a slight decrease in wood density for radiata pine and Douglas fir. Finally, Wang et al. [51] indicated that heavy thinning induced the creation of more woody knots and larger-diameter knots than the medium thinning, or where no thinning had been applied.

The general objective of this study was the evaluation of the wood mechanical properties for Calabrian pine trees occurring in a forest stand located in the "Aspromonte" National Park (Calabria, Southern Italy) using innovative non-destructive methods (stress wave techniques). In detail, the evaluation of wood quality was carried out through acoustic measurements useful for assessing the MOE. Specifically, we hypothesized that different intensities of thinning can influence the wood quality of Calabrian pine trees. Three areas characterized by different management options as well as a no-thinning area, as control, were assessed. They were characterized by similar environmental conditions, such that the only discriminating parameter was the applied silviculture.

Furthermore, we also verified if the MOEd values may be predicted by easily recordable variables such as tree diameter (D), height $(\mathrm{H}), \mathrm{H} / \mathrm{D}$ ratio, or their transformations (number of trees per hectare, basal area per hectare).

\section{Materials and Methods}

\subsection{Study Area and Experimental Design}

The study area was located in Zervò (Municipality of Santa Cristina d'Aspromonte), in the context of the Aspromonte National Park (Calabria Region-38 $14^{\prime} 30^{\prime \prime} \mathrm{N} ; 16^{\circ} 01^{\prime} 09^{\prime \prime}$ E), at an elevation of $1100 \mathrm{~m}$ a.s.l. The climate is temperate, with an annual mean temperature of around $10^{\circ} \mathrm{C}$ and minimum 
monthly means of $3{ }^{\circ} \mathrm{C}$ (coldest month) and $17^{\circ} \mathrm{C}$ (warmest month), respectively. The annual rainfall is $1508 \mathrm{~mm}$, with minimum precipitation occurring in summer, but is, however, unevenly distributed over the year (Meteorological station of Santa Cristina d'Aspromonte- $980 \mathrm{~m}$ a.s.l.). According to Pavari's phytoclimatic classification [52] the study area belongs to the Castanetum/Fagetum zone. The whole area is characterized by gently undulating slopes with northeast exposure and soils developed from high-rank metamorphic rocks, such as schist and biotitic gneisses, and classified according to the IUSS WRB [53].

The investigated forest stands are plantations of Calabrian pine which were established in 1968, with a planting density of 2000 trees per hectare $(2.0 \mathrm{~m} \times 2.5 \mathrm{~m})$. In 2007, at the age of 39 years, the whole plantation has been subject to different intensities of thinning, following a randomized block experimental design with three intensities of thinning repeated three times. Moreover, a portion of the stand was not characterized by cutting and considered as control. Then, twelve plots in total were considered in the field measurements. Each block had an extension of 5 hectares (Figure 1).



Figure 1. Location of the study area in Southern Italy (Calabrian Region) and the applied experimental design.

The treatments (intensity of thinning) can be described as follows: (1) No thinning (T0-Control); (2) Thinning where the $25 \%$ of the occurring trees were cut (T25); (3) Thinning where the $50 \%$ of the occurring trees were cut (T50); (4) Thinning where the $75 \%$ of the occurring trees were cut (T75).

\subsection{Field and Laboratory Activity}

In 2018, eleven years after the thinning operation (age of the plantation: 50 years), 804 trees were selected in total. Particular care was taken to select trees in good vegetative conditions, with canopies well separated from each other and referring to the dominant tree layer. The 804 trees were distributed between three blocks containing the four treatments, containing 201 trees for each treatment (67 trees for each replicate).

The diameter at breast height (DBH) and height of trees were measured. Moreover, for each tree, the acoustic wave tests were conducted at breast height. The measurements were conducted from June to July 2018, in order to reduce the effect of air humidity which could affect the obtained results [54]. More specifically, the relative air humidity was measured in the study area during the sampling period $1 \mathrm{~m}$ above the ground, using a HOBO1 Pro RH/Temp Data Logger (Onset Computer Corporation, Pocasset, MA, USA).

The system used for measuring acoustic velocity was the TreeSonic ${ }^{\mathrm{TM}}$ (Fakopp Enterprise, Agfalva, Hungary), a tool which has already applied in other studies [55]. This tool is characterized by an handheld hammer and two probes, a transmitting accelerometer, and a receiving accelerometer. 
The operation consists in the insertion of two sensor probes (a transmit probe and a receiver probe) into the sapwood, introducing, then, the acoustic energy into the tree through a hammer impact. The probes were aligned within a vertical plane on the same face. In our study, a $1.00 \mathrm{~m}$ testing span was roughly centered at breast height. The lower probes were placed about $60-70 \mathrm{~cm}$ above the forest floor. Three measurements were realized for each selected tree and the average of the three recordings was used as the final transit time. In order to measure the acoustic velocity wave, the start and stop sensors were driven at a $45^{\circ}$ angle through the bark and into the wood of the standing tree [56]. Indeed, the TreeSonic ${ }^{\mathrm{TM}}$ was developed to operate in the longitudinal direction of the tree. The acoustic velocity was then calculated from the span between the two sensor probes and the time-of-flight (TOF) data using the following formula (Equation (1)):

$$
\mathrm{CT}=\mathrm{S} / \mathrm{TOF}
$$

where $\mathrm{CT}=$ tree acoustic velocity $(\mathrm{m} / \mathrm{s}), \mathrm{S}=$ distance between the two probes (sensors) $(\mathrm{m}), \mathrm{TOF}=$ time of flight (s).

For determination of the MOEd, it was necessary to determine the wood density. A subsample of trees was selected, considering trees where the TOF was also measured. In detail, woody cores were extracted, bark to bark, at breast height $(1.30 \mathrm{~m})$ with a Pressler borer from trees, referring to each of the diameter classes occurring in the different treatments (three cores for each treatment and diameter class). The fresh weight and volume of the tree cores were measured in the laboratory. Samples were then weighed to the nearest 0.01 gram with an electronic scale. Oven drying of all samples was done at $105^{\circ} \mathrm{C}$ to constant weight. Density $\left(\mathrm{kg} \mathrm{m}^{-3}\right)$ was calculated by dividing the dry weight with the fresh sample volume.

Afterwards, it was possible to calculate the modulus of elasticity (MOE), according to the following equation (Equation (2)):

$$
\mathrm{MOEd}=\mathrm{WD}_{\mathrm{ij}} \cdot \mathrm{CT}^{2} \text {, }
$$

where $\mathrm{WD}_{\mathrm{ij}}=$ tree wood density $\left(\mathrm{kg} \mathrm{m}^{-3}\right)$, shared by diameter class (i) and treatment $(\mathrm{j})$; and $\mathrm{CT}=$ velocity $\left(\mathrm{m} \mathrm{s}^{-1}\right)$.

The MOE estimated using the above cited formula [57] is called the dynamic modulus of elasticity (MOEd) [58], since the stress wave propagation in wood is a dynamic process and internally related to the physical and mechanical properties of the wood [51].

\subsection{Statistical Analysis}

The preliminary shape indexes (skewness and kurtosis) were calculated, and the Shapiro-Wilk test was performed to evaluate the distribution of the acquired data. Afterwards, the analysis of variance (ANOVA), based on a scheme of randomized blocks (four treatments repeated three times), was carried out to test the differences in MOEd values obtained among the four treatments and in relation to the occurring diameter classes. The significance level of the differences was tested using Tukey's method. When the significance level ( $p$-value) was $\leq 0.05$, the null hypothesis was rejected and significant differences in the means were accepted.

For the estimation of the MOEd, the following parameters (easily measurable in the field) were considered as predictors: diameter at breast height $(\mathrm{DBH})$, height $(\mathrm{H})$, height/diameter ratio $(\mathrm{H} / \mathrm{DBH})$, basal area (BA), stand density (number of trees per hectare) and their mutual interactions.

As a preliminary analysis, the correlations between these variables and the MOEd were analyzed using the Spearman correlation coefficient (r). Subsequently, the analysis was carried out by comparing different transformations and combinations of the variables correlated with the MOEd, suitable for expressing the relationship between MOEd and the above cited variables. The process involved regression analysis with a stepwise procedure (in each step, a variable was considered for addition to or subtraction from the set of explanatory variables based on F-tests). We then evaluated the fit of the final model using and analyzing the value of root mean square error (RMSE) and the coefficient 
of determination $\left(R^{2}\right)$ value. Finally, the Shapiro-Wilk test was used to verify the normality of the error distribution.

Data analysis were carried out using the statistical software R version 3.2.5 [59].

\section{Results}

The relative air humidity measured in the study area during the sampling period ranged from $39 \%$ to $56 \%$. For each treatment, the main measured structural parameters and the derived values of stand density and basal area are reported in Table 1. The skewness and kurtosis values, as well as the Shapiro-Wilk test (SWT), revealed that all the attributes were characterized by normal distribution. Tree diameters varied from about 25 to $32 \mathrm{~cm}$, while tree heights showed similar values (19-20 m).

Table 1. The main parameters measured and the related structural characteristics for the four treatments analyzed (DBH: diameter at breast height; $\mathrm{H}$; total tree height; $\mathrm{N} \mathrm{ha}^{-1}$ : number of trees per hectare; SD: standard deviation; SWTsig: $p$-values of the Shapiro-Wilk Test).

\begin{tabular}{|c|c|c|c|c|c|c|}
\hline Treatments & Parameters & Mean & SD & Skewness & Kurtosis & SWTsig \\
\hline \multirow[t]{4}{*}{ T0 } & $\mathrm{DBH}(\mathrm{cm})$ & 24.9 & 6.07 & 0.228 & -0.408 & 0.106 \\
\hline & $\mathrm{H}(\mathrm{m})$ & 18.84 & 2.83 & 0.447 & 0.483 & 0.112 \\
\hline & Stand density $\left(\mathrm{N} \mathrm{ha}^{-1}\right)$ & 1977 & 134 & 0.468 & -0.62 & 0.125 \\
\hline & Basal area $\left(\mathrm{m}^{2} \mathrm{ha}^{-1}\right)$ & 95.9 & 7.16 & -0.873 & 0.024 & 0.095 \\
\hline \multirow[t]{4}{*}{$\mathrm{T} 25$} & $\mathrm{DBH}(\mathrm{cm})$ & 26.7 & 8.19 & 0.352 & 0.242 & 0.053 \\
\hline & $\mathrm{H}(\mathrm{m})$ & 20.03 & 2.76 & 0.298 & 0.237 & 0.131 \\
\hline & Stand density $\left(\mathrm{N} \mathrm{ha}^{-1}\right)$ & 1548 & 77 & 0.045 & -0.938 & 0.096 \\
\hline & Basal area $\left(\mathrm{m}^{2} \mathrm{ha}^{-1}\right)$ & 86.88 & 11 & 0.049 & -0.965 & 0.364 \\
\hline \multirow[t]{4}{*}{$\mathrm{T} 50$} & $\mathrm{DBH}(\mathrm{cm})$ & 26.4 & 8.73 & 0.646 & 1.001 & 0.064 \\
\hline & $\mathrm{H}(\mathrm{m})$ & 20.05 & 3.65 & -0.326 & 0.042 & 0.055 \\
\hline & Stand density $\left(\mathrm{N} \mathrm{ha}^{-1}\right)$ & 939 & 49 & 0.676 & 1.055 & 0.118 \\
\hline & Basal area $\left(\mathrm{m}^{2} \mathrm{ha}^{-1}\right)$ & 51.45 & 4.28 & -0.451 & -0.579 & 0.247 \\
\hline \multirow[t]{4}{*}{ T75 } & $\mathrm{DBH}(\mathrm{cm})$ & 32.5 & 9.96 & 0.444 & -0.46 & 0.217 \\
\hline & $\mathrm{H}(\mathrm{m})$ & 21.1 & 3.68 & -0.503 & 0.399 & 0.146 \\
\hline & Stand density $\left(\mathrm{N} \mathrm{ha}^{-1}\right)$ & 514 & 29 & -0.281 & -0.684 & 0.214 \\
\hline & Basal area $\left(\mathrm{m}^{2} \mathrm{ha}^{-1}\right)$ & 42.67 & 3.05 & 0.194 & -0.544 & 0.079 \\
\hline
\end{tabular}

Figure 2 reports the variability and the distribution of the wood density in relation to the type of treatment and the different diameter classes.

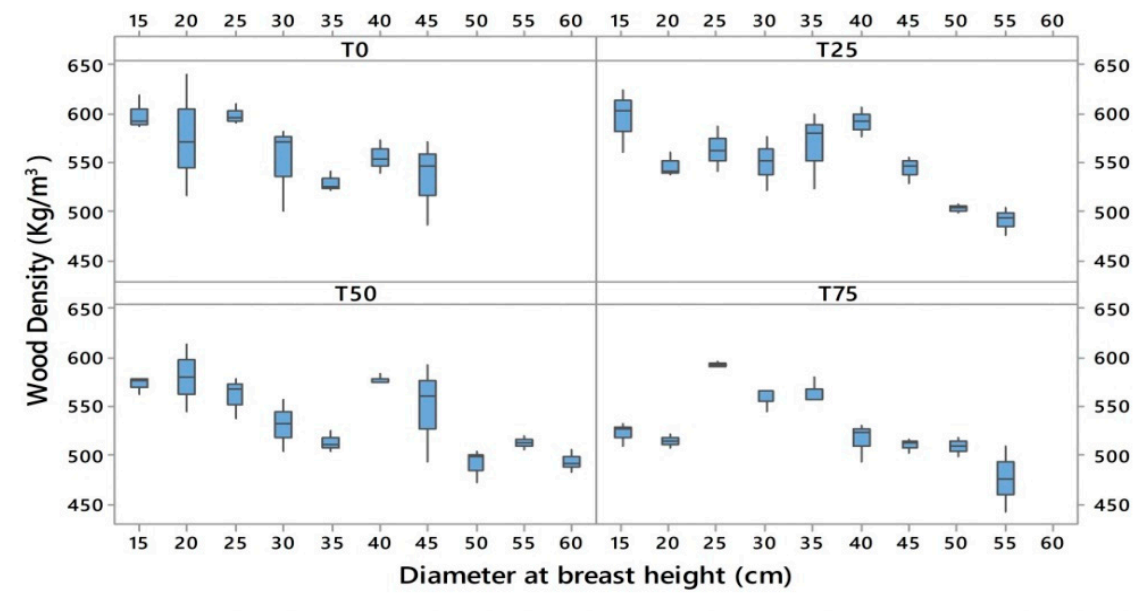

Figure 2. Variability of the tree wood density for each treatment as shared by diameter classes. 
Table 2 shows the stress wave times and the related mechanical properties (wave velocity and MOEd) for the sampled trees in relation to the different silvicultural treatments. Moreover, the tree wood density (on average) is also shown.

Table 2. Tree wood density, stress wave time, and mechanical properties for the sampled trees among the different treatments considered (SD: standard deviation; MOEd: dynamic modulus of elasticity). Means in the same column followed by the same letter are not statistically different at $p \leq 0.05$ (Tukey test).

\begin{tabular}{|c|c|c|c|c|c|c|c|c|}
\hline \multirow[t]{2}{*}{ Treatments } & \multicolumn{2}{|c|}{$\begin{array}{l}\text { Tree Wood Density } \\
\left(\mathrm{kg} / \mathrm{m}^{3}\right)\end{array}$} & \multicolumn{2}{|c|}{$\begin{array}{c}\text { Stress Wave Time } \\
(\mu \mathrm{s})\end{array}$} & \multicolumn{2}{|c|}{$\begin{array}{l}\text { Wave Velocity } \\
\quad\left(\mathrm{m} \mathrm{s}^{-1}\right)\end{array}$} & \multicolumn{2}{|c|}{ MOEd (MPa) } \\
\hline & Mean & SD & Mean & SD & Mean & SD & Mean & SD \\
\hline T0 & 563 & 30.2 & $282.5^{b}$ & 48.0 & $3637.9^{d}$ & 465 & $7206.2^{c}$ & 1699.9 \\
\hline T25 & 550 & 35.5 & $257.0^{c}$ & 27.0 & $3959.7^{a b}$ & 397 & $8487.5^{b}$ & 1695.4 \\
\hline $\mathrm{T} 50$ & 538 & 28.2 & $245.2^{\mathrm{cd}}$ & 22.0 & $4141.6^{\mathrm{a}}$ & 371 & $9275.8^{a}$ & 1717.5 \\
\hline T75 & 529 & 27.4 & $344.5^{\mathrm{a}}$ & 90.8 & $3090.1^{c}$ & 681 & $5371.9^{\mathrm{d}}$ & 2242.2 \\
\hline
\end{tabular}

With reference to the stress wave time, significant differences were recorded among the different intensities of thinning $\left(F_{3 ; 794}=134.24 ; p \leq 0.001\right)$, while no difference between blocks $\left(F_{2 ; 794}=2.012\right.$; $p=0.134)$ were observed. The treatment characterized by the higher thinning intensity (T75) revealed a longer stress wave time $(344.5 \mu \mathrm{s})$, also differing significantly with respect to all other conditions: T75 was about 22\% and 40\% higher than T0 and T50, respectively. Moreover, each treatment differs significantly in stress wave time from all the others, except T25 and T50, which had similar values.

The wave velocity is positively correlated to the thinning intensities, up to the T50 treatment (Table 2); afterwards, it significantly decreased for the higher thinning intensity $(\mathrm{T} 75)\left(F_{3 ; 794}=174.55\right.$; $p \leq 0.001)$. No differences between blocks $\left(F_{2 ; 794}=1.579 ; p=0.207\right)$ were observed.

In Figure 3, the variation of the wave velocity in relation to the tree diameter classes is reported for each treatment.

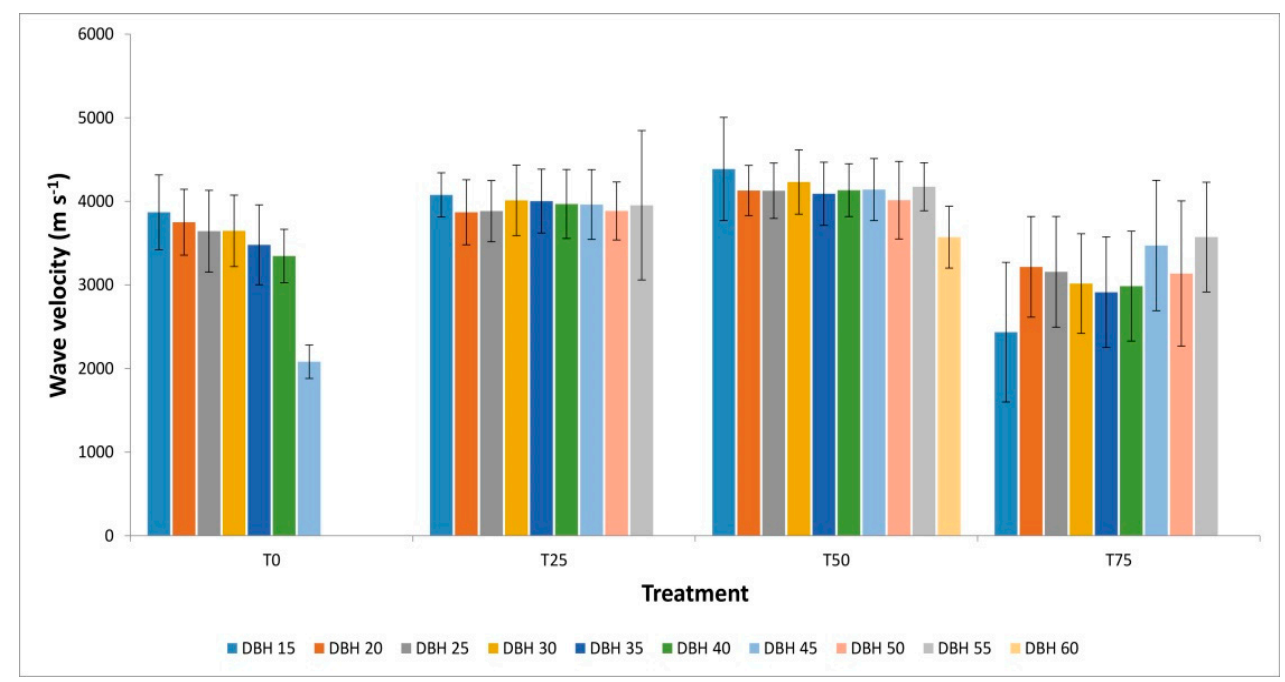

Figure 3. Wave velocity in relation to the diameter classes for each intensity of thinning. DBH: diameter at breast height. For Control, $F_{6 ; 191}=3.371 ; p=0.006$; for T25, $F_{8 ; 189}=0.658 ; p=0.728$; for T50, $F_{9 ; 188}=1.600 ; p=0.118 ;$ for $\mathrm{T} 75, F_{8 ; 189}=2.330 ; p=0.021$.

In the control plots, the wave velocity tends to decrease as the tree diameters increase; more specifically, the $45 \mathrm{~cm}$ diameter class had significant lower values when compared to all other diameter classes. No significant differences were observed between diameter classes for T25 and T50. On the contrary, the wave velocity values were the lowest for the T75 treatment, revealing significant differences also between diameter classes. 
Furthermore, Figure 4 shows the MOEd values obtained for all the sampled trees in each intensity of thinning.



Figure 4. MOEd values obtained for all the sampled trees. Different colors refer to the four intensities of thinning.

Generally, for each tree, lower values always occurred in T75, while higher values occurred in T25 and T50. The analysis of variance (ANOVA) showed a significant effect of the thinning intensity on MOEd values $\left(F_{3 ; 794}=170.82 ; p \leq 0.001\right)$. Table 2 shows that the MOEd was significantly higher in T25 (on average, equal to $8487 \mathrm{MPa}$ ) and T50 (on average, $9275 \mathrm{MPa}$ ) than in T0 (on average, $7206 \mathrm{MPa}$ ) and T75 (on average $5371 \mathrm{MPa}$ ). Furthermore, the MOEd values for treatment T75 were always lower than in the T0 (Table 2). No difference between blocks was observed $\left(F_{2 ; 794}=1.574 ; p=0.208\right)$. Furthermore, the analysis of variance showed a significant effect of the diameter classes on MOEd values for the thinning intensities T0 and T75, while no significant effects were observed in treatments T25 and T50 (Figure 5).

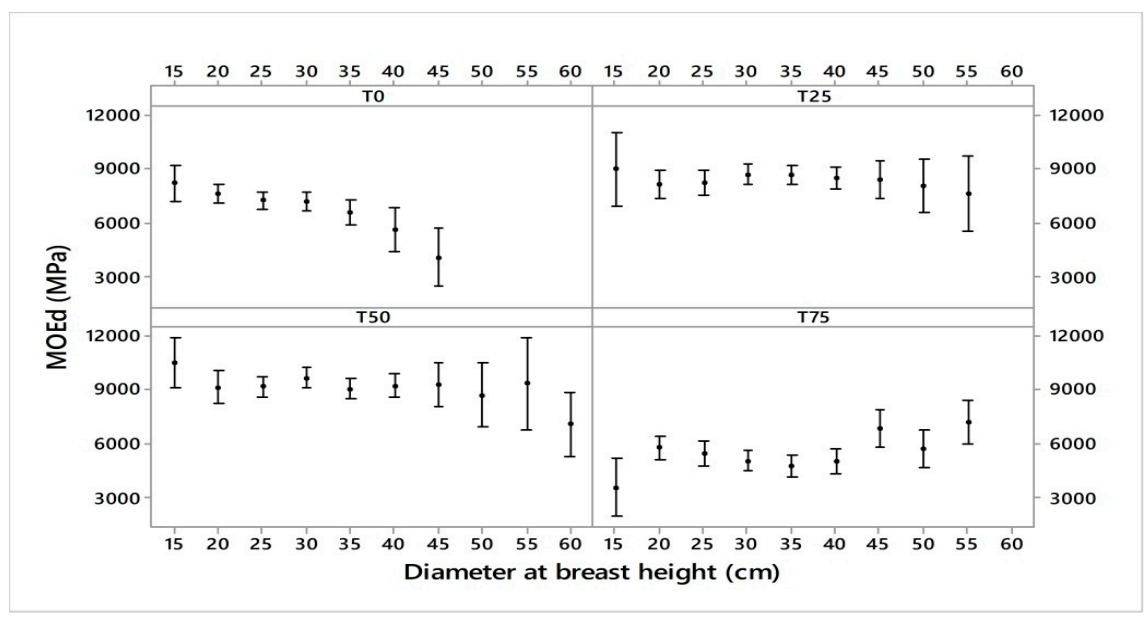

Figure 5. Dynamic modulus of elasticity (MOEd) in relation to the diameter classes for each intensity of thinning. For Control, $F_{6 ; 191}=3.371 ; p=0.006$; for T25, $F_{8 ; 189}=0.658 ; p=0.728$; for T50, $F_{9 ; 188}=1.600$; $p=0.118$; for $\mathrm{T} 75, F_{8 ; 189}=2.330 ; p=0.021$.

The MOEd values decrease as the diameters for $\mathrm{T} 0$ increase, with significant differences observed between the smallest and largest diameter classes. On the contrary, for the T25 and T50 treatments, the MOEd values were not significantly different when the diameter increased (Figure 5). The thinning, especially in the T25 treatment and, to a lesser extent, in the T50 treatment, had the effect of aligning 
the MOEd values, making the wood quality uniform in each diameter class. On the contrary, for the T75 treatment, the MOEd values not only were significantly lower than the T0, T25, and T50 treatments, but they also varied significantly with the increase of diameters.

In analyzing the best predictors for the estimation of MOEd, the applied analysis showed correlations between MOEd and DBH $(r=0.011)$, between MOEd and $\mathrm{H}(\mathrm{r}=0.040)$ and between MOEd and $\mathrm{H} / \mathrm{D}(\mathrm{r}=0.033)$ that were not considered significant. On the contrary, significant correlations emerged between the MOEd and the stand density $(\mathrm{r}=0.474)$ and basal area $(\mathrm{r}=0.217)$.

Therefore, a model that allows for computing the MOEd as a function of the stand density (number of trees per hectare) and basal area $\left(\mathrm{m}^{2}\right.$ per hectare) was applied. According to the stepwise regression procedure, the variables were combined in the following model (Equation (3)):

$$
\text { MOEd }=\beta_{0}+\beta_{1} \cdot \frac{1}{B A}+\beta_{2} \cdot S D+\beta_{3} \cdot S D^{2}+\beta_{4} \cdot S D^{3}
$$

where $B A=$ basal area per hectare; $S D=$ number of trees per hectare.

Figure 6 shows the variation of the MOEd in relation to the number of trees per hectare for different basal areas. The analysis covered a basal area lapse ranging from 40 to $70 \mathrm{~m}^{2} \mathrm{ha}^{-1}$. The MOEd curve is lower for high values of basal area $\left(70 \mathrm{~m}^{2} \mathrm{ha}^{-1}\right)$ and higher when basal area values decrease $\left(40 \mathrm{~m}^{2} \mathrm{ha}^{-1}\right)$. The root mean square error (RMSE) was $1850.69 \mathrm{MPa}$ and $\mathrm{R}^{2}$ was 0.368 . Moreover, the Shapiro-Wilk normality test $(\mathrm{W}=0.9614 ; p=0.096)$ confirmed the absence of deviation from normality. Furthermore, Table 3 reports the statistical values obtained by the application of the Equation (3).



Figure 6. MOEd values in relation to the stand density and to the basal area.

Table 3. Statistical parameters obtained in the model and their significance (BA: basal area; SD: number of trees per hectare; T: results of the Student $t$-test).

\begin{tabular}{ccccc}
\hline Model & Coefficients & $\begin{array}{c}\text { Standard Error of } \\
\text { Coefficients }\end{array}$ & T & Significance \\
\hline (Constant) & -11895.537 & 1349.925 & -8.782 & $p<0.0001$ \\
1/BA & 227408.509 & 44672.651 & 5.068 & $p<0.0001$ \\
SD & 31.669 & 2.538 & 12.458 & $p<0.0001$ \\
DD $^{2}$ & -0.018 & 0.002 & -7.941 & $p<0.0001$ \\
SD $^{3}$ & 0.00000281 & 0.000 & 5.371 & $p<0.0001$ \\
\hline
\end{tabular}

\section{Discussion}

The obtained results demonstrate how the effect of silvicultural practices on wood quality can be successfully identified by measurement of MOEd. 
The MOEd values recorded in standing trees were significantly influenced by thinning intensities, since they determined significant variations in MOEd values with respect to the control. Specifically, the T25 and T50 treatments produced significant benefits in terms of wood quality, while a higher thinning intensity (T75) induced a significant decrease of the MOEd, even lower than the control. The strong diametric increment induced by the intensive thinning probably resulted in a less-stiff mature wood, resulting in a significant loss of wood quality.

On other hand, many authors confirmed that wood quality and intrinsic wood properties are generally affected by thinning $[16,60,61]$, especially by stand density $[62,63]$. In this study, density values were measured on a subsample, rather than all, of the trees. This could lead to slight variations in MOEd values, but should not compromise the obtained results. In Southern Italy, Todaro and Macchioni [43] also found a significant variation of wood properties caused by thinning operations in a Douglas fir forest.

Generally, in the management of forest stands, it is common to apply a strong intensity of thinning in order to obtain a high assortment of diameters [64]. However, our results show that these assortments are of a lower quality compared to those derived from moderate intensities of thinning.

It is also interesting that the increase in the MOEd values from T0 to T25 is more sustained than the increase in MOEd from T25 to T50. This indicates that light thinning has a significant and positive effect on the wood quality, while increasing thinning intensities are always less significant. On the other hand, the T25 treatment had a positive effect on MOEd, both at the stand level and at the diametric class level, making the MOEd values almost equal for each diameter class. On the contrary, in the T0 and T75 treatments, we observed a decrease in wood quality when diameters increased. Other studies conducted on trees of the same age for different conifers (Sitka spruce (Picea sitchensis Bongard, Carrière, 1855), western hemlock (Tsuga heterophylla (Raf.) Sarg.), jack pine (Pinus banksiana Lamb.), ponderosa pine (Pinus ponderosa Douglas ex C. Lawson), and radiata pine (Pinus radiata D. Don) $[65,66])$ reported that the stress wave velocity was higher for trees with a slower growth rate or narrower rings.

The results obtained here are interesting on the basis of their practical and scientific applications, since they can provide useful silvicultural indications: the application of moderate thinning can favor, at least for the Calabrian pine, the formation of woody materials of good quality, regardless of the tree size from which the assortments are obtained.

More specifically, the MOEd values increase as the number of trees rise, up to 1200-1500 trees per hectare: this tree density seems to be the optimal value for obtaining the best woody materials for Calabrian pine. Briggs [67] showed that the tree acoustic velocity measured in Douglas fir increases as tree age rises, and decreases with increasing DBH; moreover, it is affected by the initial stand density.

Furthermore, higher values of basal area, when the number of trees and tree age are similar, determine lower values of the MOEd. We can then observe that a rapid diameter increment can negatively affect the wood quality.

In Douglas fir forests, Zhang [68] and Todaro and Macchioni [43] also reported that large trees deriving from higher growth rates would generally produce wood of lower stiffness. Furthermore, Chauhan and Walker [69] showed how, in fast-growing trees of radiata pine, the increased diameter with its larger second moment of inertia induced a lower tendency for high material stiffness; moreover, for trees of the same age, slow-growing trees tend to have a high stiffness, helping to sustain the trees under various environmental disturbances. Furthermore, Lasserre et al. [70] have observed that outerwood stiffness increases dramatically with stocking (and so with smaller tree DBH).

The low values of MOEd therefore appeared to be associated to a higher growth rate in trees, which adversely affects the specific gravity as well as the wood's strength and stiffness. Younger wood is lower in specific gravity and stiffness, while fast-growing wood has a larger diameter core of juvenile wood [71].

The moderate thinnings not only increase the biomass production of trees [72-74], but also improve the wood quality in trees, as highlighted in this study. However, Nakamura [75], using 
ultrasonically induced waves to assess the wood quality in larch trees, had already observed significant differences in the wave velocity and in MOEd values for forest stands characterized by different density some decades ago. In addition, Wang [48], assessing the effect of thinning treatments on the technological properties of Sitka spruce trees in southeast Alaska, showed that trees with higher acoustic velocity and stiffness were mostly found in forest stands that were uncut and/or slightly thinned, while the lowest values were found in stands subjected to high intensity thinning.

These results are encouraging, and indicate that the time of flight in the acoustic technologies may be applied, in the future, to monitor the wood property changes in forest stands. The technology can also be used to determine how silvicultural treatments affect the wood and fiber properties; consequently, the most effective treatment can be selected for maximizing the wood value, improving the timber quality of future plantations [22]. Finally, the precision of the acoustic technology has been strongly improved: nowadays, the tree quality, but also the intrinsic wood properties, can be predicted and correlated with the economic value of the final products [33].

In this study, the model developed can be used as a decision support system useful for the woody supply chain: the determination of the MOEd is fundamental for the final end uses of the woody products.

However, even if many studies have been carried out for estimating the MOEd through various non-destructive tests [76,77], few of them have, in any case, examined the relationships between MOEd and the stand structural features (e.g., stand density, DBH, total tree height, tree taper).

Gorman et al. [78] confirmed that the stress wave velocity is not affected by knots and other defects; nevertheless, it is important to underline that this method only measures the sound velocity within the outermost growth tree rings.

Furthermore, we identified, here, the most useful variables for predicting the MOEd, based on stand and tree characteristics in Calabrian pine.

In accordance with other studies [16,79-81], significant relationships between the dendrometric parameters and MOEd values were found. However, the relationships between MOEd and stand density, which showed a decrease in MOEd at high stand density, have not been previously described. While the MOEd always decreased with higher basal area, MOEd only decreased from a certain number of trees per hectare. However, in addition to the stand density (number of trees per hectare and basal area), the tree diameter classes could be considered for explaining the MOEd values in trees, as also already highlighted by Lei et al. [81]. Finally, as some of these stand structural features are commonly measured in forest inventories we provide, here, a useful tool for predicting the wood stiffness in relation to the tree and stand characteristics measured in the field. This approach allows for determination of the wood quality directly from inventory data.

However, the model used is site- and species-specific since, in other silvicultural systems, the implemented equation can differ. In any case, a pioneer of forest modeling [82] confirmed that no single model can be expected to be the "best" for all the conditions which are common in forest prediction.

\section{Conclusions}

This study showed that silvicultural practices might not only increase biomass production, but also improve the wood quality in trees. We verified here, through innovative and non-destructive methods, that different intensities of thinning can influence the wood quality of Calabrian pine trees in Southern Italy. Our results demonstrated that the effect of silvicultural practices on the properties of wood can be successfully identified by stress wave MOEd. Furthermore, we proved that MOEd values may be predicted by easily recordable variables in the field.

More specifically, for Calabrian pine, different intensities of thinning can affect the wood quality and, therefore, the final obtainable woody products. We also demonstrated that using a low intensity of thinning could be the best option for obtaining woody materials of good quality, regardless of the tree size from which the assortments derive. The results obtained are encouraging, since they demonstrate the potential of the non-destructive acoustic technique to determine the influence of 
thinning treatments performed on Calabrian pine. However, it could be interesting to also test the same methodological approach on other tree species and in different ecological contexts.

Finally, we tested a useful tool for predicting the wood stiffness in relation to tree and stand characteristics commonly measured in the field. This approach allows for determination of the wood quality directly from inventory data, even if the model used is site- and species-specific and the implemented equation can differ in other silvicultural systems.

Author Contributions: Conceptualization, D.R., P.A.M., G.M. and F.L.; Data curation, D.R. and G.M.; Formal analysis, D.R., P.A.M., G.M., A.R.P., G.Z. and F.L.; Investigation, D.R. and G.M.; Methodology, D.R., P.A.M. and F.L.; Resources, A.R.P. and G.Z.; Writing—original draft, D.R., P.A.M., G.M. and F.L.; Writing—review \& editing, P.A.M. and F.L.

Acknowledgments: We are grateful to the Aspromonte National Park for the economic support given to realize this study.

Conflicts of Interest: The authors declare no conflict of interest.

\section{References}

1. Ciancio, O.; Iovino, F.; Menguzzato, G.; Nicolaci, A.; Nocentini, S. Structure and growth of a small group selection forest of calabrian pine in Southern Italy: A hypothesis for continuous cover forestry based on traditional silviculture. For. Ecol. Manag. 2006, 224, 229-234. [CrossRef]

2. Bonavita, S.; Vendramin, G.G.; Bernardini, V.; Avolio, S.; Regina, T.M.R. The first SSR-based assessment of genetic variation and structure among Pinus laricio Poiret populations within their native area. Plant Biosyst. 2015, 150, 1-20. [CrossRef]

3. Nicolaci, A.; Travaglini, D.; Menguzzato, G.; Nocentini, S.; Veltri, A.; Iovino, F. Ecological and anthropogenic drivers of Calabrian pine (Pinus nigra J.F. Arn. ssp. Laricio (Poiret) Maire) distribution in the Sila mountain range. iForest 2014, 8, 497-508. [CrossRef]

4. Cantiani, P.; Plutino, M.; Amorini, E. Effects of silvicultural treatment on the stability of black pine plantations. Ann. Silvic. Res. 2010, 36, 49-58.

5. Duncker, P.S.; Barreiro, S.M.; Hengeveld, G.M.; Lind, T.; Mason, W.L.; Ambrozy, S.; Spiecker, H. Classification of forest management approaches: A new conceptual framework and its applicability to European forestry. Ecol. Soc. 2012, 17, 51. [CrossRef]

6. Skov, K.R.; Kolb, T.E.; Wallin, K.F. Tree size and drought affect ponderosa pine physiological response to thinning and burning treatments. J. Forensic. Sci. 2004, 50, 81-91.

7. Ostaff, D.P.; Piene, H.; Quiring, D.T.; Moreau, G.; Farrell, J.C.G.; Scarr, T. Influence of pre-commercial thinning on balsam fir defoliation by the balsam fir sawfly. For. Ecol. Manag. 2006, 223, 342-348. [CrossRef]

8. Demers, C.; Andreu, M.; McGowan, B. Thinning Southern Pines-A Key to Greater Returns; Series of the School of Forest Resources and Conservation, SS FOR 24; Florida Cooperative Extension Service, Institute of Food and Agricultural Sciences, University of Florida: Tallahassee, FL, USA, 2013; 6p.

9. Grant, C.D.; Norman, M.A.; Smith, M.A. Fire and silvicultural management of restored bauxite mines in Western Australia. Restor. Ecol. 2007, 15, 127-136. [CrossRef]

10. Zeide, B. Optimal stand density: A solution. Can. J. For. Res. 2004, 34, 846-854. [CrossRef]

11. Brissette, J.C.; Frank, R.M.; Stone, T.L.; Skratt, T.A. Precommercial thinning in a northern conifer stand: 18-year results. For. Chron. 1999, 75, 967-972. [CrossRef]

12. Machado, J.S.; Louzada, J.L.; Santos, A.J.A.; Nunes, L.; Anjos, O.; Rodrigues, J.; Simoes, R.M.S.; Pereira, H. Variation of wood density and mechanical properties of blackwood (Acacia melanoxylon r. Br.). Mater. Des. 2014, 56, 975-980. [CrossRef]

13. Jozsa, L.; Middleton, G. A Discussion of Wood Quality Attributes and Their Practical Implications; Special Publication No. SP-34; Forintek Canada Corp: Vancouver, BC, Canada, 1994.

14. Briggs, D.G.; Smith, W.R. Effects of Silvicultural Pratices on Wood Properties of Conifers: A review. In Douglas-fir Stand Management for the Future; Oliver, C., Hanley, D., Johnson, J., Eds.; University of Washington Press: Seattle, WA, USA, 1986; pp. 108-116.

15. Marziliano, P.A.; Menguzzato, G.; Scuderi, A.; Corona, P. Simplified methods to inventory the current annual increment of forest standing volume. iForest 2012, 5, 276-282. [CrossRef] 
16. Proto, A.R.; Macri, G.; Bernardini, V.; Russo, D.; Zimbalatti, G. Acoustic evaluation of wood quality with a non-destructive method in standing trees: A first survey in Italy. iForest 2017, 10, 700-706. [CrossRef]

17. Sanesi, G.; Lafortezza, R.; Colangelo, G.; Marziliano, P.A.; Davies, C. Root system investigation in sclerophyllous vegetation: An overview. Ital. J. Agron. 2013, 8, 121-126. [CrossRef]

18. Marziliano, P.A.; Lafortezza, R.; Medicamento, U.; Lorusso, L.; Giannico, V.; Colangelo, C.; Sanesi, G. Estimating belowground biomass and root/shoot ratio of Phillyrea latifolia L. in the Mediterranean forest landscapes. Ann. For. Sci. 2015, 72, 585-593. [CrossRef]

19. Škorpik, P.; Konrad, H.; Geburek, T.; Schuh, M.; Vasold, D.; Eberhardt, M.; Schuler, S. Solid wood properties assessed by non-destructive measurements of standing European larch (Larix decidua Mill.): Environmental effects on variation within and among trees and forest stands. Forests 2018, 9, 276. [CrossRef]

20. Carter, P.; Briggs, D.; Ross, R.J.; Wang, X. Acoustic Testing to Enhance Western Forest Values and Meet Customer Wood Quality Needs; Department of Agriculture Forest Service, US Department of Agriculture (USDA): Madison, WI, USA, 2005; pp. 121-129.

21. Wang, X.; Ross, R.J.; Carter, P. Acoustic evaluation of wood quality in standing trees-Part I. Acoustic wave behavior. Wood Fiber Sci. 2007, 39, 28-38.

22. Krajnc, L.; Farrelly, N.; Harte, A.M. The effect of thinning on mechanical properties of Douglas fir, Norway Spruce, and Sitka Spruce. Ann. For. Sci. 2019, 76, 3. [CrossRef]

23. Guntekin, G.; Emiroglu, Z.G.; Yolmaz, T. Prediction of bending properties for Turkish red pine (Pinus brutia Ten.) Lumber using stress wave method. BioResources 2013, 8, 231-237. [CrossRef]

24. Tsehaye, A.; Buchanan, A.H.; Walker, J.C.F. Sorting of logs using acoustics. Wood Sci. Technol. 2000, 34, 337-344. [CrossRef]

25. Wang, X.; Ross, R.J. Nondestructive Evaluation for Sorting red maple logs. In Proceedings of the 28th Annual Hardwood Symposium, West Virgina Now-The Future for the Hardwood Industry? Davis, WV, USA, 11-13 May 2000; pp. 95-101.

26. Wang, X.; Ross, R.J.; Green, D.W.; Brashaw, B.; Englund, K.; Wolcott, M. Stress wave sorting of red maple logs for structural quality. Wood Sci. Technol. 2004, 37, 531-537. [CrossRef]

27. Mora, C.R.; Schimleck, L.R.; Isik, F.; Mahon, J.M.; Clark, A.; Daniels, R.F. Relationship between acoustic variables and different measures of stiffness in standing Pinus taeda trees. Can. J. For. Res. 2009, 39, 1421-1429. [CrossRef]

28. Wessels, C.B.; Malan, F.S.; Rypstra, T. A review of measurement methods used on standing trees for the prediction of some mechanical properties of timber. Eur. J. For. Res. 2011, 130, 881-893.

29. Tenorio, C.; Moya, R.; Muñoz, F. Comparative study on physical and mechanical properties of laminated veneer lumber and plywood panels made of wood from fast-growing Gmelina arborea trees. J. Wood Sci. 2011, 57, 134-139. [CrossRef]

30. Brashaw, B.K.; Bucur, V.; Divos, F.; Goncalves, R.; Lu, J.X.; Meder, R.; Pellerin, R.F.; Potter, S.; Ross, R.J.; Wang, X.P.; et al. Non-destructive testing and evaluation of wood: A worldwide research update. For. Prod. J. 2009, 59, 7-14.

31. Aratake, S.; Arima, T. Estimation of modulus of rupture (MOR) and modulus of elasticity (MOE) of lumber using higher natural frequency of log in pile of logs. II. Possibility of application for sugi square lumber with pith. Mokuzai Gakkaishi 1994, 40, 1003-1007.

32. Ross, R.J.; McDonald, K.A.; Green, D.W.; Schad, K.C. Relationship between log and lumber modulus of elasticity. For. Prod. J. 1997, 47, 89-92.

33. Wang, X. Advanced sorting technologies for optimal wood products and woody biomass utilization. In Proceedings of the International Conference on Biobase Material Science and Engineering, Changsha, China, 21-23 October 2012; pp. 175-179.

34. Teder, M.; Pilt, K.; Miljan, M.; Lainurm, M.; Kruuda, R. Overview of some non-destructive methods for in-situ assessment of structural timber. In Proceedings of the 3rd International Conference Civil Engineering, Jelgava, Latvia, 12-13 May 2011.

35. Legg, M.; Bradley, S. Measurement of stiffness of standing trees and felled logs using acoustics: A review. J. Acoust. Soc. Am. 2016, 139, 588-604. [CrossRef] [PubMed]

36. Mochan, S.; Moore, J.; Conolly, T. Using Acoustics Tools in Forestry and the Wood Supply Chain; Forestry Commission Technical Note 18; Forestry Commission: Edinburgh, UK, 2009. 
37. Wang, X. Fundamentals of acoustic measurements on trees and logs and their implication to field application. In Proceedings of the 17th International Symposium on Non-Destructive Testing and Evaluation of Wood, Sopron, Hungary, 14-16 September 2011; pp. 25-33.

38. Wang, X. Acoustic measurements on trees and logs: A review and analysis. Wood Sci. Technol. 2013, 47, 965-975. [CrossRef]

39. Vanninen, P.; Ylitalo, H.; Sievanen, R.; Makela, A. Effect of age and site quality on the distribution of biomass in Scots pine (Pinus sylvestris L.). Trees 1996, 10, 231-238. [CrossRef]

40. Vargashernandez, J.; Adams, W.T. Genetic relationships between wood density components and cambial growth rhythm in young coastal Douglas-fir. Can. J. For. Res. 1994, 24, 1871-1876. [CrossRef]

41. Rozenberg, P.; Franc, A.; Bastien, C.; Cahalan, C. Improving models of wood density by including genetic effects: A case study in Douglas-fir. Ann. For. Sci. 2001, 58, 385-394. [CrossRef]

42. Zobel, B.J.; van Buijtenen, J.P. Wood Variation: Its Causes and Control; Springer: Berlin, Germany, 1989.

43. Todaro, L.; Macchioni, N. Wood properties of young Douglas-fir in Southern Italy: Results over a 12-year post-thinning period. Eur. J. For. Res. 2011, 130, 251-261. [CrossRef]

44. Todaro, L.; Quartulli, S.; Robusto, A.; Moretti, N. Effects of different thinning regimes on stand stability and timber assortments in a Douglas-fir forest. Ital. For. Mont. 2002, 5, 451-466, (In Italian with English Summary).

45. Schweingruber, H.S. Tree Rings: Basic and Applications of Dendrochronology; Kluwer: Dordrecht, The Netherland, 1998.

46. Wang, S.Y.; Lin, C.J.; Chiu, C.M.; Chen, J.H.; Yang, T.H. Dynamic modulus of elasticity and bending properties of young Taiwania trees grown with different thinning and pruning treatments. J. Wood Sci. 2005, 51, 1-6. [CrossRef]

47. Peltola, H.; Kilpeläinen, A.; Sauvala, K.; Räisänen, T.; Ikonen, V.P. Effects of early thinning regime and tree status on the radial growth and wood density of Scots pine. Silva Fenn. 2007, 41, 489-505. [CrossRef]

48. Wang, X. Stress Wave-Based Non-Destructive Evaluation (NDE) Methods for Wood Quality of Standing Trees. Ph.D. Dissertation, Michigan Technological University, Houghton, MI, USA, 1999; p. 187.

49. Cown, D.J. Comparison of the effects of two thinning regimeson some wood properties of radiata pine. NZ J. Forest Sci. 1974, 4, 540-551.

50. Barbour, R.J.; Foyle, D.C.; Chauret, G.; Cook, J.A.; Karsh, M.B.; Ran, S. Breast height relative density and radial growth in matureJack pine (Pinus banksiana) for 38 years after thinning. Can. J. For. Res. 1994, 24, 2439-2447. [CrossRef]

51. Wang, X.; Ross, R.J.; Mcclellan, M.; Barbour, R.J.; Erickson, J.R.; Forsman, J.W.; Mcginnis, G.D. Non-destructive evaluation of standing trees with stress wave method. Wood Fiber Sci. 2001, 33, 522-533.

52. Pavari, A. Le classificazioni fitoclimatiche ed i caratteri della stazione [Phytoclimatic classifications and station characteristics]. Scritti di Ecologia Selvicoltura e Botanica Forestale 1959, 45-116. (In Italian)

53. IUSS Working Group WRB. World Reference Base for Soil Resources; International Soil Classification System for Naming Soils and Creating Legends for Soil Maps. World Soil Resources Reports No. 106; FAO: Roma, Italy, 2014.

54. Yang, H.; Yu, L.; Wang, L. Effect of moisture content on the ultrasonic acoustic properties of wood. J. For. Res. 2015, 26, 753-757. [CrossRef]

55. Divos, F. Acoustic Tools for Seedling, Tree and Log Selection. In Proceedings of the Final Conference of COST Action E53 The Future of Quality Control for Wood and Wood Products, Edinburgh, UK, 4-7 May 2010; p. 5.

56. Eckard, J.T.; Isik, F.; Bullock, B.; Li, B.; Gumpertz, M. Selection efficiency for solid wood traits in Pinus taeda using time-of-flight acoustic and micro-drill resistance methods. For. Sci. 2010, 56, 233-241.

57. Lasserre, J.P.; Mason, E.G.; Watt, M.S. Assessing corewood acoustic velocity and modulus of elasticity with two impact based instruments in 11-year-old trees from a clonal-spacing experiment of Pinus radiata D.Don. For. Ecol. Manag. 2007, 239, 217-221. [CrossRef]

58. Urhan, O.S.; Kolpak, S.E.; Jayawickrama, K.J.S.; Howe, G.T. Early genetic selection for wood stiffness in juvenile Douglas-fir and western hemlock. For. Ecol. Manag. 2014, 320, 104-117. [CrossRef]

59. R Core Team. R: A Language and Environment for Statistical Computing; R Foundation for Statistical Computing: Vienna, Austria, 2016. 
60. Candel-Pérez, D.; Lo, Y.H.; Blanco, J.; Chiu, C.M.; Camarero, J.; González de Andrés, E.; Imbert, J.; Castillo, F. Drought-induced changes in wood density are not prevented by thinning in Scots pine stands. Forests 2018, 9, 4. [CrossRef]

61. Mitchell, S.J. Stem growth responses in Douglas-fir and Sitka spruce following thinning, implications for assessing wind-firmness. For. Ecol. Manag. 2000, 135, 105-114. [CrossRef]

62. Todaro, L. Influenza delle tecniche colturali sulle qualità del legno di alcune conifere con particolare riferimento alla Douglasia [Influence of silvicultural treatments on wood quality on Douglas-fir trees]. Monti e Boschi 2002, 3/4, 3844. (In Italian)

63. Macdonald, H.; Hubert, J. A review of the effect of silviculture on timber quality of Sitka spruce. Forestry 2002, 2, 107-138. [CrossRef]

64. Štefančík, I.; Vacek, Z.; Sharma, R.P.; Vacek, S.; Rösslová, M. Effect of thinning regimes on growth and development of crop trees in Fagus sylvatica stands of Central Europe over fifty years. Dendrobiology 2018, 79, 141-155.

65. Ikeda, K.; Kino, N. Quality evaluation of standing trees by a stress-wave propagation method and its application I. Seasonal changes of moisture contents of sugi standing trees and evaluation with stress-wave propagation velocity. Mokuzai Gakkaishi 2000, 46, 181-188.

66. Wang, X.; Ross, R.J.; Punches, J.; Barbour, R.J.; Forsman, J.W.; Erickson, J.R. Evaluation of small-diameter timber for valued-added manu-facturing-A stress wave approach. In Proceedings of the II International Precision Forestry Symposium; Institute of Forest Resources, University of Washington: Seattle, WA, USA, 2003; pp. 91-96.

67. Briggs, D.G.; Thienel, G.; Turnblom, E.C.; Lowell, E.; Dykstra, D.; Ross, R.; Wang, X.; Carter, P. Influence of thinning on acoustic velocity of douglas-fir trees in western Washington and western Oregon. In Proceedings of the 15th International Symposium on Non-destructive Testing of Wood, Duluth, MN, USA, 10-12 September 2007; Forest Products Society: Madison, WI, USA, 2008; pp. 113-123.

68. Zhang, S.Y. Effect of growth rate on wood specific gravity and selected mechanical properties in individual species from distinct wood categories. Wood Sci. Technol. 1995, 29, 451-465. [CrossRef]

69. Chauhan, S.S.; Walker, J.C.F. Variations in acoustic velocity and density with age, and their interrelationships in radiata pine. For. Ecol. Manag. 2006, 229, 388-394. [CrossRef]

70. Lasserre, J.P.; Mason, E.; Watt, M. The influence of initial stocking on corewood stiffness in a clonal experiment of 11 year-old Pinus radiata D. Don. N. Z. J. Forestry 2004, 49, 18-23.

71. Clark, A.; Daniels, R.F. Modelling the effect of physiographic region on wood properties of planted loblolly pine in southeast United States. In Proceedings of the Connection between Forest Resources and Wood Quality: Modelling Approaches and Simulation Software, Fourth Workshop IUFRO Working Party S5.01-04, Harrison Hot Springs, BC, Canada, 8-15 September 2002; p. 663.

72. Marziliano, P.A.; Coletta, V.; Menguzzato, G.; Nicolaci, A.; Pellicone, G.; Veltri, A. Effects of planting density on the distribution of biomass in a douglas-fir plantation in southern Italy. iForest 2015, 8, 368-376. [CrossRef]

73. Coletta, V.; Menguzzato, G.; Pellicone, G.; Veltri, A.; Marziliano, P. Effect of thinning on above-ground biomass accumulation in a Douglas-fir plantation in southern Italy. J. For. Res. 2016, 27, 1313-1320. [CrossRef]

74. Marziliano, P.A.; Menguzzato, G.; Scuderi, A.; Scalise, C.; Coletta, V. Biomass conversion and expansion factors in Douglas-fir stands of different planting density: Variation according to individual growth and prediction equations. For. Syst. 2017, 26, e003. [CrossRef]

75. Nakamura, N. Measurement of the properties of standing trees with ultrasonics and mapping of the properties. Univ. For. Res. 1996, 96, 125-135.

76. Sandoz, J.L. Non-destructive testing of wood. In Proceedings of the 10th International Symposium on NDT, Lausanne, Switzerland, 26-27 August 1996.

77. Zhang, S.Y.; Chauret, G.; Ren, H.Q.; Desjardins, R. Impact of plantation black spruce initial spacing on lumber grade yield, bending properties and MSR yield. Wood Fiber Sci. 2002, 34, 460-475.

78. Gorman, T.M.; Wagner, F.G.; Wu, S.Y. Assessment of intensive stress-wave scanning of Douglas-fir trees for predicting lumber modulus of elasticity. In Proceedings of the 13th International Symposium on Nondestructive Testing of Wood, Richmond, BC, Canada, 19-21 August 2002; pp. 143-148.

79. Castera, P.; Faye, C.; El Ouadrani, A. Prevision of the bending strength of timber with a multivariate statistical approach. Ann. For. Sci. 1996, 53, 885-898. [CrossRef] 
80. Haartveit, E.Y.; Flate, P.O. Mechanical properties of Norway spruce lumber from monocultures and mixed stand-modelling bending stiffness and strength using stand and tree characteristics. In Proceedings of the Connection between Silviculture and Wood Quality: Modelling Approach and Simulation Software, IUFRO WP S5.01-04 Workshop, Harrison Hot Springs, BC, Canada, 8-15 September 2002; p. 2002.

81. Lei, Y.C.; Zhang, S.Y.; Jiang, Z. Models for predicting lumber bending MOR and MOE based on tree and stand characteristics in black spruce. Wood Sci. Technol. 2005, 39, 37-47. [CrossRef]

82. Burkhart, H.E. Development of empirical growth and yield models. In Proceedings of the Empirical and Process-Based Models for Forest Tree and Stand Growth Simulation, A Workshop/Ph.D. Course Jointly Organized by Technical University of Lisbon and IUFRO 4.01, Oeiras, Portugal, 21-27 September 1997; p. 10.

2019 by the authors. Licensee MDPI, Basel, Switzerland. This article is an open access article distributed under the terms and conditions of the Creative Commons Attribution (CC BY) license (http://creativecommons.org/licenses/by/4.0/). 